\title{
Correction to: Proceedings of the 2nd International Conference on Experimental and Computational Mechanics in Engineering
}

\author{
Akhyar
}

\section{Correction to:}

Akhyar (ed.), Proceedings of the 2nd International

Conference on Experimental and Computational Mechanics in Engineering, Lecture Notes in Mechanical Engineering, https://doi.org/10.1007/978-981-16-0736-3

The original version of the book was inadvertently published with incorrect author names in chapters 15 and 44. The names have been corrected and details of the changes have been provided below:

Chapter "The Effect of Atmosphere Media on Temperature and Mass of Torrefacted Coffee Beans":

M. Faisal has been changed to Faisal

Chapter "Fly Ash Utilization in Rigid Pavement Construction":

Nasruddin A. Abdullah has been changed to Abdullah

The correction chapters and the book have been updated with changes.

The updated versions of these chapters can be found at https://doi.org/10.1007/978-981-16-0736-3_15,

https://doi.org/10.1007/978-981-16-0736-3_44 